\title{
Correlations of the Mechanisms Involved in Diabetes Mellitus, Peripheral Arterial Disease and Gangrene Leading to Amputations - a Retrospective Study Over the Non-traumatic Amputations Performed in the Emergency Clinical County Hospital of Arad Between 2014-2018
}

\author{
ROXANA FURAU1", AMORIN REMUS POPA ${ }^{2 \#, ~ C R I S T I A N ~ F U R A U 1,6, ~ C R I N G U ~ I O N E S C U 3,5, ~ M I H A I ~ D I M I T R I U 3,5 \#, ~}$ \\ GHEORGHE OTTO FURAU1,6, RADU STEFAN ROMOSAN"\#, BOGDAN SOCEA ${ }^{3,5 * \#, ~ N I C O L A E ~ G H E O R G H I U, ~}{ }^{5,7 \#,}$ \\ DIANA CLAUDIA GHEORGHIU33, ANDREI KORODI ${ }^{1 \#}$ \\ ${ }^{1}$ Vasile Goldis Western University of Arad, Faculty of Medicine, 86 Liviu Rebreanu Str., 310414, Arad, Romania \\ 2 University of Oradea, 1 University Str., Oradea 410087, Romania \\ ${ }^{3}$ Sf. Pantelimon Emergency Clinical Hospital, 340-342 Pantelimon Road, 021659, Bucharest, Romania \\ ${ }^{4}$ Victor Babes University of Medicine and Pharmacy, 2 Eftimie Murgu Sq., 30077, Timisoara, Romania \\ ${ }^{5}$ Carol Davila University of Medicine and Pharmacy, 37 Dionisie Lupu Str., 020021, Bucharest, Romania \\ ${ }^{6}$ Emergency Clinical County Hospital of Arad, 2-4 Andreny Karoly Str., 310037, Arad, Romania \\ ${ }^{7}$ Elias Emergency Hospital 17 Marasti Str., 011461, Bucharest, Romania
}

\begin{abstract}
Diabetes mellitus (DM) is, undoubtedly, an important risk factor of peripheral artery disease (PAD), leading to increased and severe complications, as well as for primary or associated dermatological lesions, all of which leading to radical therapeutic measures, as amputations are. DM and its complications have an important effect on life expectancy and quality of life, which can be quantified using disability-adjusted life year (DALY) as universal metric that allows researchers and policymakers to compare very different populations and health conditions across time. In the last five years these medical conditions have had a detrimental effect on the whole Arad County society, with a magnitude of premature deaths (YLL ) of 1,779 years and a value for Years Lost due to Disability (YLD) of 20,795, DALY reaching 22,574. These figures have to change completely the existent DM control measures for better protection of patients' health and improving their quality of life.
\end{abstract}

Keywords: Diabetes mellitus, amputations, DALY

Diabetes mellitus (DM), peripheral arterial disease (PAD) and gangrene are complications which can lead to extreme surgical procedures such as amputations, that are irreversible, mutilating, and strongly affecting quality of life determinants as much as some cancers do [1].

DM selectively damages endothelial and mesangial cells, whose glucose transport rates do not decline rapidly as a result of hyperglycemia, leading to high glucose inside the cell [2]. There are four main mechanisms involved in diabetic's cells' distructions: the first is the polyol pathway and increased polyol pathway ûux, described in peripheral nerve [3], with an effect on decreasing nerve conduction velocity in the DM patients. The second mechanism was described by increased formation of advanced glycation end products (AGEs) [4], these AGE precursors can diffuse out of the cell modifying extracellular matrix molecules nearby, causing cellular dysfunction by modifying circulating proteins in the blood such as albumin, proteins which can then bind to AGE receptors and activate them, thereby causing the production of inûammatory cytokines and grow th factors, which in turn cause vascular pathology. The third pathway: hyperglycemia-induced activation of protein kinase C (PKC) isoforms [5]; many abnormal vascular and cellular processes, including endothelial dysfunction, vascular permeability, angiogenesis, cell growth and apoptosis, changes in vessel dilatation, basement membrane thickening and extracellular matrix expansion, enzymatic activity alterations such as mitogenactivated protein kinase (MAPK), cytosolic phospholipase A2 (PLA2), Na+-K+-ATPase and alterations in several transcription factors, are attributed to multiple PKC isoforms that are changed by DM [6]. The fourth mechanism: increased hexosamine pathway flux and consequent overmodiûcation of proteins by $\mathrm{N}$ acetylglucosamine are followed by a high concentration of glucose which may lead to glucosamine formation, with consequences in Nitric oxide-mediated dilatation of arterioles [6].

PAD is listed as one of the diseases derived from atherosclerosis, so its understanding should be focus on the pathophysiological role played by inûammation [7], which is fundamental connected both in triggering PAD and in augmenting it. The endothelium is highly to endowed in nitric oxide generation (NO) and its release. Because NO release lowers endothelial barrier damag; since endothelial dysfunction is considered an early signal of atherosclerosis, reduction in NO bioactivity as well as the increased generation of oxygen free radicals (or reactive oxygen species ROS) are effective players in endothelial dysfunction [8].

C-reactive protein (CRP), an acute-phase protein of hepatic origin, inhibits the release of NO, promotes the release of endothelial monocyte chemo-attractor protein1 (MCP-1) and tissue factor. It is strongly associated with the increased risk of atherosclerotic cardiovascular disease independent of cholesterol level [9-12].

Interleukin-6 GG genotype contributes to the development of PADs among individuals with Type 2 DM [13]. IL-1 contributes in PAD development to extending inflammatory activity, leading to cell proliferation (i.e., neutrophils) [14]. A shortfall in IL-10 has been associated to increased atherosclerotic plaque [15]. 
Selectin (S) is a family of three closely related glycoproteins [14]. P-Selectin is highly involved in the atherosclerotic process affecting platelet aggregation, promoting the up-regulation of tissue factor which plays a crucial role in determining arterial thrombosis [15]. Increased E-selectin plasma levels were found in PAD patients with Type $2 \mathrm{DM}$.

Matrix Metalloproteinases (MMPs) are a family of Zinc $2+$ dependent enzymes involved in platelet aggregation, thus suggesting a possible role in the atherosclerotic process [8]. The results of MMP studies have shown that MMP 2 and 9 might be useful in marking macrovascular damage in PAD patients and in Type 2 DM [16-19].

\section{Gangrene}

It has been demonstrated that inhalation of $\mathrm{O}_{2}$ at pressures greater than 1ATA (atmosphere absolute) as it happens in hyperbaric oxygen therapy, increase production of ROS, which are in the same time signaling molecules in transduction cascades or pathways for a variety of growth factors, cytokines [16], and hormonal substances, with a beneficial role in chronic non-healing leg-diabetic wounds, associated with vascular insufficiency due to accelerated atherosclerotic process $[17,20]$.

We studied upper and lower-extremity nontraumatic amputations performed between 2014-2018 in Arad County, taking into account DM complications, PAD and dermatological related lesions, focused on burden of disease as is reflected in disability-adjusted life years (DALY) and Kaplan-Meier estimation for hospital stay. This subject was partially treated before [21], without PAD as main contributor.

\section{Aim}

Identification of all nontraumatic upper and lowerextremity amputations in relation to DM, PAD and skin disorders in Arad inpatients between 2014-2018.

\section{Hypotheses}

The alternative hypothesis: there is more risks for nontraumatic amputations in PAD and DM patients compared to dermatological ones. The null hypothesis: all patients are at the same risks for nontraumatic amputation.

\section{Experimental part}

Material and methods

Electronic hospital database was scanned for all DRG (Diagnosis Related Groups) cases as listed in Romanian Tables of RO DRG related to upper and lower-extremity amputations as well as nontraumatic diseases codes identified as causes for these procedures. A retrospective chart review of medical records for all inpatients was the basis for a descriptive epidemiological study which was performed by calculating DALY according to Arad County population registered in the official demographic records $[22,23]$. Years of Life Lost due to premature mortality (YLL) was calculated by totalling the number of deaths at each age between 1-79 years for women and between 1-71.6 years for men, multiplied by the number of years of life remaining up to the age of 79 years for women and 71.6 for men, according to the Life Expectancy tables [24]. Univariate analyses were used to identify significant differences in variables for inpatients. Chi square testing was destinated to compare intergroup variation between nonparametric variables; logistic regression model was designed to evaluate independent associations between demographics, and significant clinical variables identified from univariate analyses. Odds ratios (OR) and 95\% confidence intervals were calculated for each variable in the regression models. Statistics were performed with IBM SPSS ${ }^{\circledR}$ Statistics 24, MedCalc ${ }^{\circledR}$ and Epi Info $® 7$.

\section{Results and discutions}

In total ten thousand eighthundred seventy-five $(10,875)$ patients were assisted in the hospital; 6,439 for DM; 4,101 for dermatological conditions (of which 1,188 presented both) and 335 for PAD. Inpatients age-categories and death

\begin{tabular}{|c|c|c|c|c|c|}
\hline Age category & survival & deceased & total & cases to 10,000 & $\begin{array}{l}\text { death rate } \\
\text { to } 10,000\end{array}$ \\
\hline aged 0-4 & 101 & 0 & 101 & 48.97 & 0 \\
\hline aged $5-9$ & 44 & 0 & $44^{-}$ & 18.95 & 0 \\
\hline aged $10-14$ & 79 & 0 & 79 & 34.32 & 0 \\
\hline aged 15-19 & 120 & $0^{-}$ & 120 & 48.39 & 0 \\
\hline aged $20-24$ & 75 & $0^{-}$ & 75 & 27.66 & 0 \\
\hline aged $25-29$ & 88 & 0 & 88 & 24.09 & 0 \\
\hline aged 30-34 & $104^{-}$ & 0 & 104 & 31.03 & 0 \\
\hline aged $35-39$ & $159^{-}$ & 1 & 160 & 40.88 & 0.26 \\
\hline aged $40-44$ & 324 & 0 & 324 & 82.01 & 0.00 \\
\hline aged $45-49$ & 577 & 5 & -582 & $141.34^{-}$ & 1.21 \\
\hline aged $50-54$ & 918 & $7^{-}$ & 925 & 356.26 & $2.70^{-}$ \\
\hline aged $55-59$ & 1,603 & 17 & 1,620 & 507.52 & 5.33 \\
\hline aged $60-64$ & 1,741 & $32^{-}$ & 1,773 & $561.43^{-}$ & 10.13 \\
\hline aged $65-69$ & $-1,606$ & 28 & $1,634^{-}$ & 626.22 & -10.73 \\
\hline aged $70-74$ & $-1,202$ & $44^{-}$ & 1,246 & 785.62 & 27.74 \\
\hline aged $75-79$ & $1,074^{-}$ & 27 & $-1,101^{-}$ & 673.89 & 16.53 \\
\hline aged $80-84$ & $621^{-}$ & 23 & $644^{-1}$ & 624.82 & $22.31^{-}$ \\
\hline 85 and over & 236 & 19 & 255 & 352.06 & 26.23 \\
\hline total & 10,092 & 203 & 10,276 & 360.40 & 7.12 \\
\hline
\end{tabular}

Table 1

INPATIENTS AGE CATEGORIES W ITH PREVALENCE AND DEATH RATES TO 10.000 


\begin{tabular}{|c|c|c|c|}
\hline item & $\mathrm{DM}$ & Dermatology & $\mathrm{PAD}$ \\
\hline \multicolumn{4}{|l|}{ sociodemographic } \\
\hline mean age & 62.35 & 59.16 & 68.83 \\
\hline $\mathrm{SD}$ & 12.769 & 18.713 & 11.742 \\
\hline \multicolumn{4}{|l|}{ gender } \\
\hline $\mathrm{F}$ & 3586 & 2100 & 93 \\
\hline $\mathrm{M}$ & 2853 & 2001 & 242 \\
\hline \multicolumn{4}{|l|}{ residence } \\
\hline rural & 3210 & 2097 & 159 \\
\hline urban & 3229 & 2004 & 176 \\
\hline \multicolumn{4}{|l|}{ evolution } \\
\hline progressive & 28 & 2 & 10 \\
\hline improved & 5555 & 3761 & 174 \\
\hline deceased & 172 & 10 & 21 \\
\hline stationary & 130 & 26 & 16 \\
\hline recovered & 554 & 302 & 114 \\
\hline total cases & 6439 & 4101 & 335 \\
\hline \multicolumn{4}{|l|}{ Death rate } \\
\hline $\mathrm{F}$ & 2.31 & 0.28 & 9.67 \\
\hline $\mathrm{M}$ & 3.11 & 0.19 & 4.95 \\
\hline Mean hospital stay & 8.24 & 7.91 & 10.11 \\
\hline \multicolumn{4}{|l|}{ procedures } \\
\hline incision, excision and drainage & 61 & 178 & 3 \\
\hline upper extremities amputation & 11 & 0 & 0 \\
\hline lower extremities amputation & 686 & 7 & 122 \\
\hline upper extremity amputation & 11 & 0 & 0 \\
\hline arterial bypass and endarterectomy & 5 & 0 & 4 \\
\hline abscess drainage & 5 & 4 & 0 \\
\hline wound debridement & 227 & 492 & 16 \\
\hline embolectomy & 1 & 0 & 36 \\
\hline skin grafting & 2 & 60 & 0 \\
\hline wound dressing & 1 & 5 & 1 \\
\hline varicose vein treatment & 0 & 15 & 0 \\
\hline
\end{tabular}

Table 2

INPATIENTS CHARACTERISTICS rates, as listed in table 1 , shows that age-category prevalence was greater for those aged 70-74, deaths included.

Gender mean age was higher for women 62.98 years $(n=5,779$; Standard Deviation SD 15.233) and 59.49 years for men $(n=5,096$; SD 15.363). Gender ratio F:M was almost equal 1.13:1. Table 2. Death rate was $2.06 \%$ for $M$ $(n=105)$ and $1.69 \%(n=98)$ for $F$, with notable differences: for DM death rate was $3.11 \%$ in $\mathrm{M}$ and $2.31 \%$ in $\mathrm{F}$; for dermatology was $0.19 \%$ for $M$ and $0.28 \%$ for $F$. Interesting, in PAD death rate for women was $9.677 \%$ and for men was 4.95\%. Amputation of lower limb rates in DM inpatients were $10.65 \%$ and $0.17 \%$ for upper limb. In dermatology amputation rate was $0.17 \%$ for lower limb. In PAD were met only lower extremities amputations at the highest rate of $36.41 \%$.

Relative Risk (RR) for PAD is 2.9509 for men compared to women $(95 \% \mathrm{Cl} 2.3302$ to $3.7369, \mathrm{P}<0.0001)$ and chance (OR) for PAD is 3.0482 for men compared to women $(95 \% \mathrm{Cl} 2.3926$ to $3.8834, \mathrm{P}<0.0001)$. RR for DM is slightly higer 1.1084 for men compared to women (95\% $\mathrm{Cl} 2.3302$ to $3.7369, \mathrm{P}<0.0001$ ) and OR for DM is 1.2856 for men compared to women $(95 \% \mathrm{Cl} 1.1907$ to 1.3881 , $\mathrm{P}$
$<0.0001$ ). RR for dermatological diseases is 1.0806 for men compared to women $(95 \% \mathrm{Cl} 1.0296$ to $1.1340, \mathrm{P}=$ $0.0017)$ and $\mathrm{OR}$ is 1.1327 for men compared to women $(95 \% \mathrm{Cl} 1.0480$ to $1.2241, \mathrm{P}=0.0017)$.

Upper and lower-extremity amputations were performed on patients between 38 - 95 years of age, to 233 women and 593 men, gender ration M:F being $2.54: 1$ $(P<0.0001)$. RR for amputation is 2.8862 for men compared to women $(95 \% \mathrm{Cl} 2.4921$ to $3.3425, \mathrm{P}<0.0001)$ and OR for amputation is 3.1346 for men compared to women $(95 \% \mathrm{Cl} 2.6803$ to $3.6658, \mathrm{P}<0.0001)$. RR for death after amputation is 2.3957 compared to conservative procedures $(95 \% \mathrm{Cl} 1.7680$ to $3.2461, \mathrm{P}<0.0001)$ and OR for death after amputation is 2.6965 compared to conservative procedures $(95 \% \mathrm{Cl} 1.8675$ to $3.8936, \mathrm{P}<$ $0.0001)$. The death rate not related to amputation was $1.68 \%$, while death rate related to amputation was $4.55 \%$. Overall death rate was $1.87 \%$ with the highest value for PAD, 6.27\%, table 3 .

Mean survival according to hospital stay was 111.44 days for PAD (Standard Error SE 4.788), 72.69 for DM (SE 3.365) and 53.37 for dermatological inpatients, (SE 1.439) Figure 1, Kaplan Meier survival curve.

\begin{tabular}{|c|c|c|c|c|c|}
\hline & \multicolumn{2}{|c|}{ Number of events } & \multicolumn{2}{|c|}{ Number censored } & \\
\hline Factor & death & \%death & $\mathrm{N}^{-}$ & $\%$ & Total sample size \\
\hline PAD & 21 & 6.27 & 314 & 93.73 & 335 \\
\hline dermatology & $10^{-}$ & $0.24^{-}$ & $-4,091$ & $99.76^{-}$ & 4,101 \\
\hline $\mathrm{DM}^{-}$ & 172 & 2.67 & 6,267 & $97.33^{-}$ & 6,439 \\
\hline Overall & 203 & 1.87 & 10,672 & 98.13 & 10,875 \\
\hline
\end{tabular}

Table 3

DEATH CASES SUMMARY 


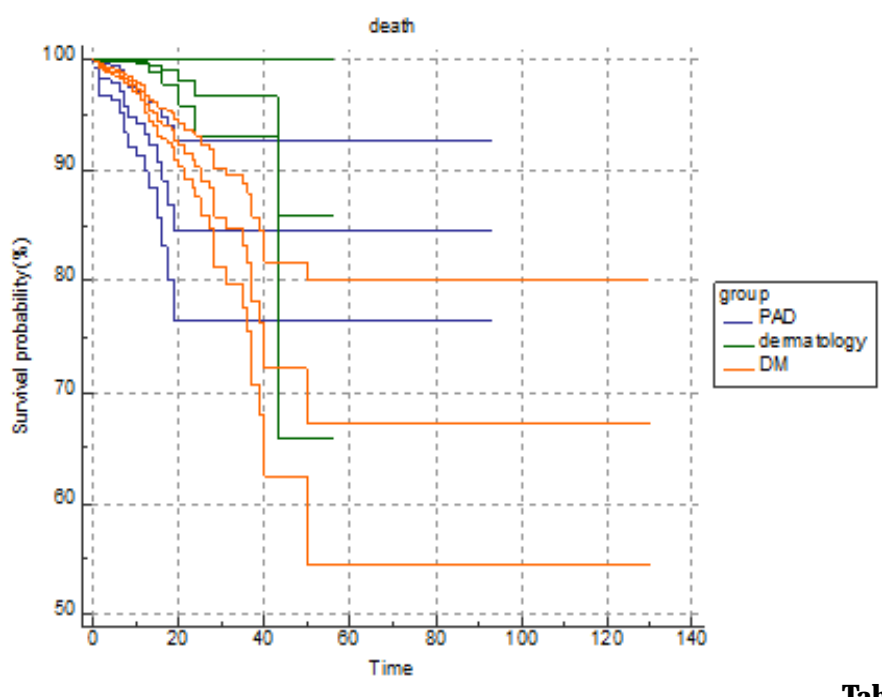

Fig.1. Kaplan Meier survival curve

Table 4

YLL FOR DM, PAD AND RELATED DERMATOLOGICAL CONDITIONS OVER 2014-2018

\begin{tabular}{|c|c|c|c|c|c|c|}
\hline & Deaths & $\begin{array}{l}\text { Deaths per } \\
1,000\end{array}$ & $\begin{array}{l}\text { Av. Age at } \\
\text { death }\end{array}$ & Standard LE & YLLs & $\begin{array}{l}\text { YLL per } \\
1,000\end{array}$ \\
\hline \multicolumn{7}{|l|}{ Males } \\
\hline $35-39$ & 1 & 0.05 & 37.5 & 32.0 & 21 & 1.0 \\
\hline $40-44$ & 0 & 0.00 & 42.6 & 27.5 & & $0.0^{-}$ \\
\hline $45-49$ & 4 & 0.19 & 47.7 & 23.4 & 67 & 3.3 \\
\hline $50-54$ & 4 & 0.31 & 52.6 & 19.7 & 59 & 4.6 \\
\hline $55-59$ & 9 & $0.60^{\circ}$ & 57.6 & 16.0 & 114 & 7.6 \\
\hline $60-64$ & 24 & 1.68 & $62.7^{\circ}$ & $12.7^{-}$ & 254 & 17.8 \\
\hline $65-69$ & 12 & 1.03 & 67.7 & 9.8 & 102 & 8.7 \\
\hline $70-74^{\circ}$ & 21 & 3.24 & $72.6^{-}$ & 7.4 & 139 & 21.5 \\
\hline $75-79$ & 12 & 1.94 & 77.5 & 5.8 & 63 & 10.3 \\
\hline $80-84$ & 11 & 2.93 & $82.4^{-}$ & 4.5 & 46 & 12.2 \\
\hline $85+$ & 7 & 2.95 & 89.0 & 2.9 & 20 & 8.3 \\
\hline Total & 105 & 0.46 & 69.1 & 10.1 & 885 & 3.8 \\
\hline \multicolumn{7}{|c|}{ Females } \\
\hline $45-49$ & 1 & 0.05 & 47.7 & 30.5 & 20 & 1.0 \\
\hline $50-54^{-}$ & 3 & 0.23 & 52.6 & 25.5 & 53 & 4.1 \\
\hline $55-59$ & 8 & 0.48 & $57.7^{-}$ & 19.9 & 120 & 7.1 \\
\hline $60-64$ & 8 & 0.46 & 62.6 & 16.8 & 106 & 6.1 \\
\hline $65-69$ & 16 & 1.11 & 67.6 & 13.8 & 180 & 12.5 \\
\hline $70-74$ & 23 & $2.45^{\circ}$ & 72.6 & 10.1 & 201 & 21.4 \\
\hline $75-79$ & 15 & 1.48 & 777.6 & 8.1 & $107^{-}$ & 10.6 \\
\hline $80-84$ & 12 & 1.83 & 82.6 & $6.4^{-}$ & $70^{-}$ & 10.6 \\
\hline $85+$ & 12 & 2.47 & $90.0^{-}$ & 3.2 & 36 & $7.4^{-}$ \\
\hline Total & 98 & 0 & 73.0 & 11.1 & 894 & 3.7 \\
\hline
\end{tabular}

Abbreviations: Av. Age at death =average age at death; Standard LE=Standard life expectancy; YLL= Years of life lost

Years of life lost (YLL) is an indicator which takes into account the age at which premature deaths occur by giving greater weight to deaths at younger age and lower weight to deaths at older age [22]. Disability-Adjusted Life Year (DALY) is another quantifier of the Burden of Disease from mortality and morbidity; DALYs are calculated as the sum of the YLL due to premature mortality in the population and the Years Lost due to Disability (YLD) for people living with a specific health condition or its consequences [25].

YLL is calculated by totalling the number of deaths at each age between 1-79.1 years for women and between 1-71.7 years for men, multiplied by the number of years of life remaining up to the age of 79.1 years for women and 71.7 for men, according to the Life Expectancy tables [19], added up to 1,779 years in men and women for all cases in this study. DALY was established with calculation template available on World Health Organization site [26].

Premature death YLL selects mainly men aged 60-64 and women aged 70-74 cut also affects active for society individuals aged 45-59 both gender, YLLs for them being 433 , meaning $24.33 \%$ of all premature deaths, Table 4.
Total mortality accounted for $7.88 \%$ of DALY, meaning $8.44 \%$ for men and $7.38 \%$ for women, table 5 .

YLDs induced by all these three health conditions were 9,590 for men and 11,205 for women, total 20,795. DALYs, or burden of disease were 22,574 in men and women $(10,475$ in men and 12,098 in women). YLDs accounted for $92.119 \%$ of DALY for all inpatients. The burden in men, and the share of the YLD component in men reached $46.40 \%$ of total DALY. For women the YLD component reached $53.59 \%$ of total DALY, Table 6 . YLD selects mainly inpatients aged 60-69, without regard to gender, total YLD $=14,298$.

Mortalityalone does notgive a real picture of the burden of disease, but DALY is capable to give an indication of the overall burden of it. One DALY represents the loss of the equivalent of one year of full health. Using DALYs, the burden of diseases that cause premature death but little disability (such as drowning or measles) can be compared to that of diseases that do not cause death but do cause disability 


\begin{tabular}{|c|c|c|c|c|c|}
\hline & Deaths & $\begin{array}{l}\text { Deaths per } \\
1,000\end{array}$ & $\begin{array}{l}\text { Av. Age at } \\
\text { death }\end{array}$ & YLLs & $\begin{array}{l}\text { YLL per } \\
1,000\end{array}$ \\
\hline \multicolumn{6}{|l|}{ Males } \\
\hline $30-44$ & 1 & 0.0 & 37.5 & 21 & 0.4 \\
\hline $45-59$ & 17 & 0.3 & 54.1 & 241 & 5.0 \\
\hline $60-69^{-}$ & 36 & 1.4 & 64.3 & 356 & 13.7 \\
\hline $70-79$ & $33^{-}$ & $2.6^{-}$ & 74.3 & 202 & $16.0^{\circ}$ \\
\hline $80+$ & 18 & 2.9 & $85.0^{-}$ & 66 & 10.7 \\
\hline Total- & 105 & 0.5 & 69.1 & 885 & 3.8 \\
\hline \multicolumn{6}{|c|}{ Females } \\
\hline $45-59$ & 12 & 0.2 & 55.6 & 193 & 3.8 \\
\hline $60-69^{-}$ & 24 & 0.8 & 66.0 & 286 & 9.0 \\
\hline $70-79$ & 38 & 1.9 & 74.6 & 309 & 15.8 \\
\hline $80+$ & 24 & 2.1 & 86.3 & 106 & 9.3 \\
\hline Total & 98 & 0.4 & 73.0 & 894 & 3.7 \\
\hline
\end{tabular}

Table 5

YLL IN STUDY AGE GROUPS FOR DM, PAD AND RELATED DERMATOLOGICAL CONDITIONS

\begin{tabular}{|c|c|c|c|c|c|c|}
\hline & Incidence & $\begin{array}{l}\text { Incidence } \\
\text { per } 1,000\end{array}$ & $\begin{array}{l}\text { Age at } \\
\text { onset }\end{array}$ & $\begin{array}{l}\text { Duration } \\
\text { (years) }\end{array}$ & YLDs & $\begin{array}{l}\text { YLD per per } \\
1,000\end{array}$ \\
\hline \multicolumn{7}{|l|}{ Males } \\
\hline $0-4$ & 30 & 0 & 2.5 & 0.0 & & 0.0 \\
\hline $5-14$ & 45 & 0 & 10.0 & 0.0 & & 0.0 \\
\hline $15-29$ & 145 & $0^{-}$ & 22.5 & $0.0^{\circ}$ & & 0.0 \\
\hline $30-44^{-}$ & $354^{\circ}$ & 0 & 37.5 & 0.0 & & 0.0 \\
\hline $45-59$ & 1,497 & 0 & $52.5^{-}$ & 0.0 & & 0.0 \\
\hline $60-69$ & 1,668 & 2 & 65.0 & 10.0 & $7,205^{-1}$ & $277.5^{\circ}$ \\
\hline $70-79$ & $840^{\circ}$ & $10^{-}$ & 75.0 & 5.0 & 1,950 & 154.2 \\
\hline $80+$ & 303 & 30 & 85.0 & 3.0 & $435^{\circ}$ & 71.0 \\
\hline Total & 4,882 & 21.2 & 60.0 & 4.5 & $9,590^{-1}$ & 41.7 \\
\hline \multicolumn{7}{|c|}{ Females } \\
\hline $0-4$ & 46 & 0 & 2.5 & 0.0 & & 0.0 \\
\hline $5-14$ & $55^{-}$ & 0 & 10.0 & 0.0 & & 0.0 \\
\hline $15-29$ & 110 & 0 & 22.5 & 0.0 & 0 & 0.0 \\
\hline $30-44$ & 184 & 0 & 37.5 & 0.0 & 0 & 0.0 \\
\hline $45-59$ & 1,508 & 0 & 52.5 & 0.0 & 3 & 0.1 \\
\hline $60-69$ & 1,642 & 3 & 65.0 & 10.0 & 7,093 & $223.7^{-}$ \\
\hline $70-79^{-}$ & 1,430 & 15 & 75.0 & 5.0 & 3,320 & 169.8 \\
\hline $80+$ & 550 & 40 & 85.0 & $3.0^{\circ}$ & 789 & 69.0 \\
\hline Total' & 5,525 & 22.7 & 63.3 & 4.6 & 11,205 & 45.9 \\
\hline
\end{tabular}

Abbreviations: YLD = Years Lost due to Disability

\begin{tabular}{|c|c|c|c|c|c|c|}
\hline \multicolumn{7}{|c|}{ Total DALYS = YLL+YLD } \\
\hline & Males & & Females & & Persons & \\
\hline Age & DALYs & $\begin{array}{l}\text { DALYs } \\
\text { perl, } 000\end{array}$ & DALYs & $\begin{array}{l}\text { DALYs } \\
\text { perl }, 000\end{array}$ & DALYs & $\begin{array}{l}\text { DALYs } \\
\text { perl }, 000\end{array}$ \\
\hline $30-44$ & 21 & 0.4 & & & 21 & 0.2 \\
\hline $45-59$ & 241 & 5.0 & 96 & 3.9 & 437 & 4.4 \\
\hline $60-69$ & 7,561 & 291.2 & 7,379 & 232.7 & 14,940 & $259.0^{\circ}$ \\
\hline $70-79$ & 2,152 & 170.2 & 3,628 & 185.6 & $5,781^{-}$ & 179.5 \\
\hline $80+$ & 500 & 81.7 & 895 & 78.3 & 1,395 & 79.5 \\
\hline Total & 10,475 & 45.5 & 12,098 & 49.6 & 22,574 & 47.6 \\
\hline
\end{tabular}

Table 6

YEARS LOST DUE TO DISABILITY

Table 8

BURDEN OF NONTRAUMATIC AMPUTATIONS IN ARAD COUNTY, 2014-2018

\begin{tabular}{|c|c|c|c|c|c|c|c|c|c|}
\hline & $\begin{array}{l}\text { Deaths per } \\
1,000\end{array}$ & $\begin{array}{l}\text { Av. Age } \\
\text { at death }\end{array}$ & YLLs & $\begin{array}{l}\text { YLL per } \\
1,000\end{array}$ & $\begin{array}{l}\text { Age at } \\
\text { onset }\end{array}$ & $\begin{array}{l}\begin{array}{l}\text { Duration } \\
\text { (years) }\end{array} \\
\end{array}$ & YLDs & $\overline{\text { DALYs }}$ & $\begin{array}{l}\text { DALYs } \\
\text { per } 1,000\end{array}$ \\
\hline \multicolumn{10}{|l|}{ Males } \\
\hline $30-44$ & & & & & 37.5 & 0.0 & & & \\
\hline $45-59$ & 0.1 & 56.4 & 53 & 1.1 & 52.5 & $0.0^{-}$ & & 53 & 1.1 \\
\hline $60-69^{-}$ & 0.2 & 63.5 & 61 & 2.4 & 65.0 & $10.0^{-}$ & $1,037^{-}$ & 1,098 & 42.3 \\
\hline $70-79$ & 0.4 & 74.5 & $30^{-}$ & 2.4 & $75.0^{\circ}$ & $5.0^{-}$ & $316^{-}$ & 346 & 27.4 \\
\hline $80+$ & $0.7^{-}$ & 84.1 & 15 & $2.5^{-}$ & 85.0 & 3.0 & $73^{--}$ & 88 & 14.5 \\
\hline Total' & 0.1 & 69.2 & 160 & 0.7 & 65.4 & 5.5 & $1,426^{-}$ & 1,586 & 6.9 \\
\hline \multicolumn{10}{|c|}{ Females } \\
\hline $30-44$ & & & & & 37.5 & 0.0 & 0 & & \\
\hline $45-59$ & & & & & 52.5 & 0.0 & 0 & & \\
\hline $60-69$ & 0.2 & 66.6 & 58 & 1.8 & 65.0 & 10.0 & $380^{\circ}$ & 438 & 13.8 \\
\hline $70-79$ & $0.4^{-}$ & 75.1 & $64^{-}$ & 3.3 & $75.0^{-}$ & 5.0 & 186 & 249 & 12.8 \\
\hline $80+$ & 0.4 & 84.4 & 20 & 1.8 & 85.0 & 3.0 & $55^{\circ}$ & 75 & 6.6 \\
\hline Total & 0.1 & 74.8 & 142 & 0.6 & $70.1^{-}$ & 6.0 & 620 & $763^{-}$ & 3.1 \\
\hline
\end{tabular}

Table 7

TOTAL DALYS FOR DM, PAD AND DERMATOLOGICAL CASES 
[27], (such as cataract causing blindness or amputation causing a devastating and life-changing experience).

Finally, amputations only, as disease burden, were responsible, in five years, of 2,348 DALYs for all persons, of which 1,586 were for men and 763 for women, with premature total deaths YYL of 302 and YDLs of 2,046, tabel 8 , representing $10 \%$ of total DALYs, $9.83 \%$ of YLDs and $16.97 \%$ of YYLS.

\section{Conclusions}

DM-associated atherosclerosis can lead to complications in all major of vascular beds, including the coronary arteries, carotid vessels, and lower extremity arteries $[28,-30]$. Free radicals are implied in these mechanisms [31,32]. Antioxidant mechanisms are activated and antioxidant treatments try to limit the consequences [33]. Moreover, $20-30 \%$ of patients with PAD have DM, although this is likely underestimated by the asymptomatic nature of less severe PAD and the altered pain perception in diabetic patients due to peripheral neuropathy [34]. Revascularization attempts can often be difficult [35]. Here is how the perception of a problem can be changed by the angle of view from which we look [3644]. This study emphasised the connection between them in terms of pathophysiological mechanisms and severity of complications, both having a huge impact as DALYS contributors, shortening life expectancy and dramatically decreasing the quality of life.

\section{References}

1.TATARU AL, FURAU, G; et al, J ournal of clinical medicine, 8, no. 1, 2019, Article Number 96

2.MICHAEL BROWNLEE, Banting Lecture 2004, Diabetes, 54, 2005. 3.GABBAY KH, MEROLA LO, FIELD RA, Science, 151, 1966, p. 209210.

4.VARUN PARKASH SINGH, ANJANA BALI, et al, Korean J Physiol Pharmacol., 18, 2014, p. 1-14.

5.PEDRO GERALDES, GEORGE L KING, Circ Res., 106, no. 8, 2010, p. 1319-1331

6.TIMEA BELEZNAIA, ZSOLT BAGIA, Vascul Pharmacol., 56, no. 3-4, 2012, p. 115-121.

7.SALVATORE SANTO SIGNORELLI, ELISA MARINO AND SALVATORE SCUTO, Multidisciplinary Scientific Journal, 2, 2019, p. 142-151. 8.SANDOO A, VAN ZANTEN, et al, Open Cardiovasc. Med. ., 4, 2010, p. 302-312.

9.RIDKER PM, TRACY RP, et al, N. Engl. J. Med., 336, 1997, p. 973-979. 10.MURABITO, J.M., KEYES, M.J .et al, Atherosclerosis, 203, 2009, p. 509-514.

11.VLADU, I.M, RADU, L, GIRGAVU, S.R, BALEANU, V., CLENCIU, D., ENE, C.G., SOCEA, B., MAZEN, E., CRISTEA, O.M., MOTA, M., TENEA COJAN, T.S., Rev. Chim. (Bucharest), 69, no. 11, 2018, p. 4229.

12.SOCEA, B., RADU, L., CLENCIU, D., TENEA COJAN, T.S., BALEANU, V., ENE, C.G., GIRGAVU, S.R., VLADU, I.M., Rev. Chim. (Bucharest), 69, no. 11, 2018, p. 4012.

13.LIBRA, M.SIGNORELLI, S.S. BEVELACQUA, et al, J. Clin. Pathol., 59, 2006, p. 211-215.

14.MALLAT Z, BESNARD S, et al, Circ. Res., 85, 1999, p. 17-24. 15.MERTEN, M., THIAGARAJ AN, P., Z. Kardiol., 93, 2004, p. 855-863 16.MITRANOVICI, M.I., PUSCASIU, L, et al,Rev. Chim. (Bucharest), 68, no. 12, 2017, p. 2970-2973.

17.SIGNORELLI SS, MALAPONTE G, et al., Vasc. Med., 10, 2005, p. 16.

18.UIVAROSAN D, ABDEL-DAIM M., et al, Farmacia, 66, no. 5, 2018, p. 826-830.

19.SOCEA B, NICA AA, SMARANDA A, CARAP AC, CONSTANTIN VD. Biomarkers predicting acute necrotizing enterocolitis in decompensated diabetes. Proceedigs of Interdiab 2019, Niculescu Editure, ISSN 2393-3488, p. 350.

20.SOCEA, B., CONSTANTIN, V., CARAP, A., MOCULESCU, C., COSTEA, D., POPA, F., GALAJDA, Z., Chirurgia (Bucharest), 106, no. 5, 2011, p.627.

21.TOMA IR, PRECUP C, et al, Rom J Leg Med, 26, 2018, p. 441-446.

22.***The population of Romania by localities on 1 January 2016. National Institute of Statistics, ISSN: 2066-2181.

23.POPA, AR, VESA, C.M., UIVAROSAN, D., JURCA, C.M., ISVORANU, G., SOCEA, B., STANESCU, AMA., IANCU, M.A., SCARNECIU, I., ZAHA, D.C, Rev. Chim. (Bucharest), 70, no. 1, 2019, p. 156.

24.***Life Expectancy tables, https://www.health.ny.gov/health care/ medicaid/publications

25.***https://www.who.int/whosis/whostat2006YearsOfLifeLost.pdf

26.***www. who.int/healthinfo/bodreferencelifetabletemplate.xls

27.***www.who.int/gho/mortality burden disease/daly rates/text/en/ 28.THIRUVOIPATI T, EKIELHORN C, ARMSTRONONG EJ , World J Diabetes., 6, no. 7, 2019, p. 961-969.

29.POP A, CLENCIU D, ANGHEL M, RADU S, SOCEA B, MOTA E, MOTA M, PANDURU NM; ROMDIANESTUDY GROUP, Journal of Diabetes, 8, no. 2, 2016, p. 220.

30.CLENCIU, D, TENEA COJAN, TS, DIJ MARESCU, AL, ENE, CG, DAVITOIU, DV, BALEANU, VD, CIORA, CA, SOCEA, B, VOICULESCU, DI, NEDELCUTA, RM, CALBOREAN, V, GHEORMAN, V, VLADU, IM, Rev. Chim. (Bucharest), 70, no. 4, 2019, p. 1434.

31.MANEA, M, MARCU, D, STOIAN, AP, GAMAN, MA, GAMAN, AM, SOCEA, B, NEAGU, TP, STANESCU, AMA, BRATU, OG, DIACONU, CC, Rev. Chim. (Bucharest), 69, no. 11, 2018, p. 4180.

32.GHEORGHE, G, PANTEA STOIAN, A, GAMAN, MA, SOCEA, B, NEAGU, TP, STANESCU, AMA, BRATU, OG, MISCHIANU, DLD, SUCEVEANU, AI, DIACONU, CC, Rev. Chim. (Bucharest), 70, no. 2, 2019, p. 651.

33.SOCEA, LI, SARAMET, G, SOCEA, B, DRAGHICl, C, Rev. Chim. (Bucharest), 57, no. 12, 2006, p. 1242.

34.MARSO SP, HIATT WR., J Am Coll Cardiol., 47, 2006, p. 921-929. 35.SOCEA B, CONSTANTIN V, DIMITRIU L, CARAP A, MOCULESCU C, COSTEA D, POPA F. Arch Balk Med Union, 48, no. 1, 2013, p. 51-55. 36.DIMITRIU, M, SOCEA, B, IONESCU, CA, PLES, L, GHEORGHIU, DC, CONSTANTIN,VD, CIRSTOVEANU, CG, BACALBASA, N, FURAU, CG, DAVITOIU, DV, GHEORGHIU, N, Rev. Chim. (Bucharest), 70, no. 4, 2019. p. $1248-1250$.

37.DIMITRIU, M, SOCEA, B, PLES, L, GHEORGHIU, DC, GHEORGHIU, $\mathrm{N}$, NEACSU, A, CIRSTOVEANU, CG, BACALBASA, N, FURAU, CG, FURAU, GO, BANACU, M, IONESCU, CA, Rev. Chim. (Bucharest), 70, no. 3, 2019, p. 1058-1061.

38.DIMITRIU, MCT, IONESCU, CA, GHEORGHIU, DC, SOCEA, LI, BRATU, OG, CONSTANTIN, VD, PLES, L, NEACSU, A, BOBIC, S, SOCEA, B, ReV. Chim. (Bucharest), 69, no. 9, 2018, p. 2391-2395.

39.NEACSU, A, CALIN, A, BRAILA, AD, NAVOLAN, D, DIMITRIU, M, STANICA, CD, IOAN, R, IONESCU, C, Rev. Chim. (Bucharest), 69, no. 7, 2018, p. 1796-1801

40.SOCEA, B, SOCEA, LI, BRATU, OG, MASTALIER, B, DIMITRIU, M, CARAP, A, CONSTANTIN, VD, Mat. Plast., 55, no. 1, 2018, p. 79-81.

41.SOCEA, B, CARAP, A, BRATU, OG, DIACONU, CC, DIMITRIU, M, SOCEA, LI, BOBIC, S, CONSTANTIN, VD, Mat. Plast. (Bucharest), 55, no. 2, 2018, p. 146.

42.IONESCU AC, POPESCU I, BANACU M, MATEI A, BOHILTEA R, DIMITRIU M, $5^{\text {TH }}$ ROMANIAN CONGRESS OF THE ROMANIAN SOCIETY OF ULTRASOUND IN OBSTETRICS AND GYNECOLOGY, Proceedings, Filodiritto Editori, 2017, P. 194-198.

43.ORBAN H, STAN G, GHEORGHIU N, et al, Chirurgia (Bucharest), 107, no. 2, 2012, p. 226-230.

44.ORBAN HB, GHORGHIU N, CRISTESCU V, Chirurgia (Bucharest), 105, no. 3, 2010, p. 365-372.

Manuscript received: 22.05 .2018 